\title{
Multilevel inventory techniques for minimizing cost-a case study Mukesh Bhagoria ${ }^{1}$, C. M Sadiwala ${ }^{2}$ and V.K.Khare ${ }^{3}$ \\ ${ }^{1}$ Mech. Dept. Manit, Bhopal;, ${ }^{2}$ Director, RGPV Bhopal;; ${ }^{3}$ Mech. Dept. Manit Bhopal, M.P-462003, India. mukeshbhagoria@yahoo.com
}

\begin{abstract}
The inventory problems of most of the manufacturing or trading organization are of great concern. The end item has independent demand and all its component and parts have dependent demand. These component and parts of end item are produced at different stages of production process. Thus, manufacturing of these dependent materials is done at multilevel. Depending upon the capacity of production, cost of setup and carrying inventories, the various parts and components are produced or procured at different level. MRP computes these requirements of material as per time schedule. In order to fulfill these demands of materials at multilevel situation, the production or procurement orders are released for economic batch or lot quantities. In the present paper, the order quantity or lot sizing is obtained by minimizing the cost of ordering plus the cost of carrying the item in stock certainly. Apart from that some constraint such as the availability of space and storing the inventory of these multiple items need to be taken into account.
\end{abstract}

Keywords: Inventory management, MRP, LOT for LOT, carrying costs, changeover costs.

\section{Introduction}

Manufacturing inventories consist of raw material and finished components, subassemblies and finished component in stock and in process. In order to establish these manufacturing inventories providing accurate information about the requirement of material, time at which it is required, quantity of material on hand i.e. inventory and work in process and quantity of requirement to be ordered of manufacturing. The computer is used to calculate, share and provide this information. This method of inventory management is called material requirement planning (MRP) (Enss, 2002; Ashayeri et al., 2006; Grubbstrom, 2006; Jose et al., 2007).

The MRP system is a practical inventory control method development around 1960 to handle large amount of record keeping, material requirement data, inventory status of material and their cost, interlinking the production with procurement of materials, controlling the stock and deliveries. It controls the manufacturing resources and flow of material much more efficiently and accurately. In MRP system lot sizing is required for fulfilling end product demand which is independent. The demand for subassemblies, component parts and raw material stock is derived from planned production level of end products and is dependent on end item demand. Such a multilevel production/inventory situation involves production and procurement of various materials as per bill of material of various final products according to master production schedule. The level $O$ represents the end product and its demand is fixed by customer order and forecasted as per market needs. The single level lot sizing technique would be applied to level- 1 .The level O is fixed and level 1 is controlled by some lot sizing rule. The multilevel lot sizing problem is to determine the production of lower level items (level
Research article

CIndian Society for Education and Environment (iSee)
2, 3 etc.) economically. For deciding this economic policy at more than one level, production selection of lot sizing rule is complicated and decision based on economic criteria alone may be misleading. Lot sizing in MRP system is to calculate the order quantity for production of net unfilled requirements of an item at each level of manufacturing. The order quantity must be such that it will minimize the cost of setup or ordering and cost of carrying the item in stock (Khare \& Sadiwala, 1987; Enns, 1999; Enns, 2001; Tang, 2004; Choi \& Enns, 2004;

Table 1. Indicated different level for the manufacturing of cC LMV \begin{tabular}{|c|c|c|c|c|c|}
\hline Level O & \multicolumn{5}{|c|}{ LMV } \\
\hline Level 1 & \multicolumn{2}{|c|}{ Engine assembly } & Tank & Wheel assembly & Frame \\
\hline Level 2 & Motor & Carburetor & - & Hub assembly & Tire \\
\hline
\end{tabular} Table 2. Bill of material

\begin{tabular}{|c|c|c|c|c|}
\hline $\begin{array}{c}\text { Parent } \\
\text { Code }\end{array}$ & $\begin{array}{c}\text { Component } \\
\text { code }\end{array}$ & $\begin{array}{c}\text { Level } \\
\text { code }\end{array}$ & Description & $\begin{array}{c}\text { Component } \\
\text { required }\end{array}$ \\
\hline & 800 & $\mathrm{O}$ & 800 cc LMV & 1 \\
\hline 800 & EA & 1 & Engine assembly & 1 \\
\hline & GT & 1 & Tank & 2 \\
\hline & WA & 1 & Wheel assembly & 1 \\
\hline & F & 1 & Frame & 1 \\
\hline EA & M & 2 & Motor & 1 \\
\hline & C & 2 & Carburetor & 2 \\
\hline WA & HA & 2 & Hub assembly & 1 \\
\hline & T & 2 & Tire & 1 \\
\hline
\end{tabular}
Table 3. Inventory status

\begin{tabular}{|c|c|c|c|c|c|c|}
\hline $\begin{array}{l}\text { Item } \\
\text { code }\end{array}$ & $\begin{array}{c}\text { On } \\
\text { hand }\end{array}$ & $\begin{array}{l}\text { Safety } \\
\text { stock }\end{array}$ & $\begin{array}{l}\text { Lot } \\
\text { size }\end{array}$ & $\begin{array}{l}\text { Lead } \\
\text { time }\end{array}$ & \multicolumn{2}{|c|}{ Schedule receipt } \\
\hline & & & & & Qty & Weeks \\
\hline 800 & 500 & 200 & LFL & 1 & - & - \\
\hline EA & 300 & 100 & 500 & 1 & 1000 & 10 \\
\hline GT & 600 & 200 & LFL & 2 & 900 & 10 \\
\hline WA & 500 & 400 & 500 & 1 & 2000 & 10 \\
\hline $\mathrm{F}$ & 600 & 0 & 2000 & 3 & 2000 & 10 \\
\hline $\mathrm{M}$ & 800 & 0 & LFL & 1 & - & - \\
\hline $\mathrm{C}$ & 150 & 100 & 2000 & 2 & - & - \\
\hline $\mathrm{HA}$ & 100 & 0 & LFL & 1 & 2400 & 11 \\
\hline $\mathrm{T}$ & 500 & 500 & 1000 & 3 & 3000,2000 & 11,12 \\
\hline
\end{tabular}


Table 4. Master production schedule: \#800 LMV

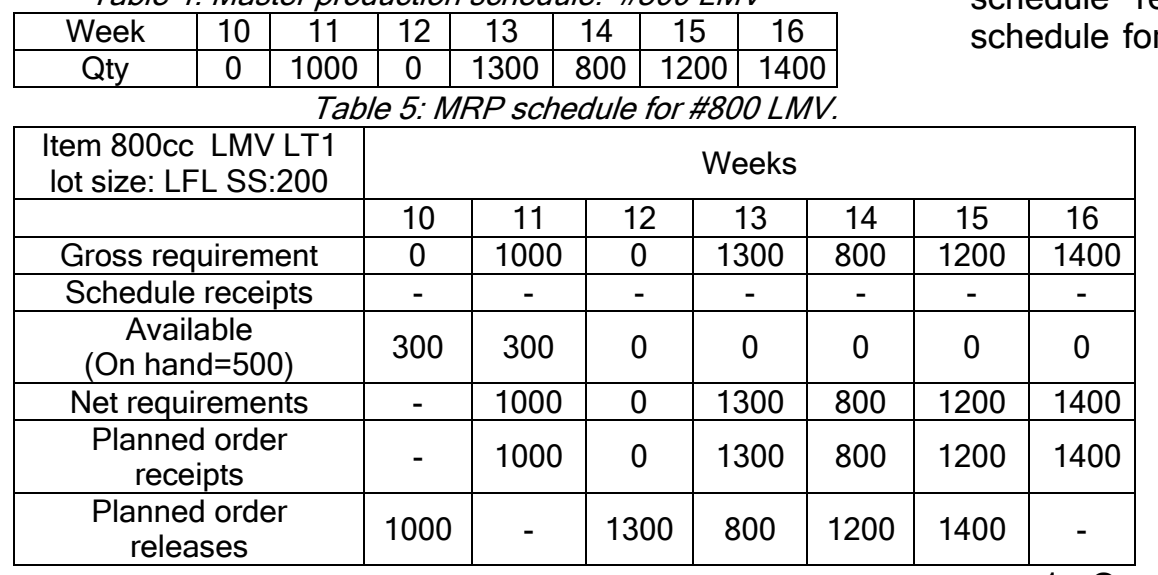

Vol. 3 No. 6 (June 2010)

ISSN: 0974- 6846

The case study includes the determination of the MRP schedule required to support the master production $5)$.

MRP schedule for \#800 cc LMV for Weeks 10-16, considering that:

1. Gross Requirements come from the LMV MPS

2. There is an on-hand balance of $500 \mathrm{LMV}$ at the end of week 9

3. There are no scheduled receipts for LMV

4. A lot-for-lot rule is used for ordering LMV

5. Safety stock of $200 \mathrm{LMV}$ is desired

6. Lead time for LMV is one week

MRP schedule for tanks for weeks 10-16, considering that (Table 6):

Table 6 MRP schedule for tanks (start prod on 1000 LMV wk 10 so they will be complete by wk 11)

\begin{tabular}{|c|c|c|c|c|c|c|c|}
\hline \multirow{2}{*}{$\begin{array}{l}\text { Item 800cc LMV LT } 2 \\
\text { lot size: LFL SS:200 }\end{array}$} & \multicolumn{7}{|c|}{ Weeks } \\
\hline & 10 & 11 & 12 & 13 & \multirow{2}{*}{$\begin{array}{c}14 \\
1200\end{array}$} & \multirow{2}{*}{$\begin{array}{c}\frac{15}{1400} \\
\end{array}$} & \multirow{2}{*}{$\begin{array}{l}16 \\
0\end{array}$} \\
\hline Gross requirement & \multirow{2}{*}{1000} & 0 & 1300 & 800 & & & \\
\hline Schedule receipts & & - & - & - & - & - & - \\
\hline $\begin{array}{c}\text { Available (On } \\
\text { hand }=600)\end{array}$ & 1300 & \begin{tabular}{l|l}
300 & 3
\end{tabular} & 300 & 0 & 0 & 0 & 0 \\
\hline Net requirements & - & 16 & 1000 & 800 & 1200 & 1400 & - \\
\hline $\begin{array}{c}\text { Planned order } \\
\text { receipts }\end{array}$ & - & 10 & 1000 & 800 & 1200 & 1400 & - \\
\hline Planned order releases & 1000 & \begin{tabular}{l|l|}
800 & 12 \\
\end{tabular} & \begin{tabular}{|l|l|}
1200 & 1 \\
\end{tabular} & \begin{tabular}{l|l}
400 \\
\end{tabular} & - & - & - \\
\hline \multicolumn{8}{|c|}{ Table 7. MRP schedule for engine frames } \\
\hline \multirow[t]{2}{*}{$\begin{array}{c}\text { Item 800cc LMV LT } 3 \\
\text { lot size: } 2000 \text { SS:0 }\end{array}$} & \multicolumn{7}{|c|}{ Weeks } \\
\hline & 10 & 11 & 12 & 13 & 14 & 15 & 16 \\
\hline Gross requirement & 1000 & 0 & 1300 & 800 & 1200 & 1400 & 0 \\
\hline Schedule receipts & 2000 & 0 & - & - & - & - & - \\
\hline Available (On hand $=600$ & 2600 & 1600 & \begin{tabular}{l|l|}
0 & 1600
\end{tabular} & 300 & 1500 & 300 & 900 \\
\hline Net requirements & 0 & \begin{tabular}{l|l} 
& 0 \\
\end{tabular} & \begin{tabular}{l|l} 
& 0 \\
\end{tabular} & 500 & 0 & 1100 & 0 \\
\hline Planned order receipts & - & - & - & 2000 & 0 & 2000 & - \\
\hline Planned order releases & 2000 & - & 2000 & - & - & - & - \\
\hline
\end{tabular}

1. Gross requirements come from LMV plannedorder-releases

2. There is an on-hand balance of 600 tanks at the end of week 9

3. There is a scheduled receipt for 900 tanks in week

4. A lot-for-lot rule is used for ordering tanks

5. Safety stock of 200 tanks is desired

6. Lead time for tanks is two weeks

MRP Schedule for frames for weeks 10-16, considering that (Table 7):

1. Gross requirements come from LMV plannedorder-releases

2. There is an on-hand balance of 600 frames at the end of week 9

3. There is a scheduled receipt for 2000 frames in week 10

4. The firm uses a lot size (multiple) of 2000 for ordering frames

5. No safety stock of frames is desired

6 . Lead time for frames is 3 weeks.

MRP schedule for engine assemblies for weeks 10-

16, considering that (Table 8):

Table 8. MRP schedule for engine assemblies

\begin{tabular}{|c|c|c|c|c|c|c|c|}
\hline $\begin{array}{c}\text { Item 800cc LMV LT 1 } \\
\text { Lot Size: 500 SS:100 }\end{array}$ & \multicolumn{7}{|c|}{ Weeks } \\
\hline & 10 & 11 & 12 & 13 & 14 & 15 & 16 \\
\hline Gross requirement & 1000 & 0 & 1300 & 800 & 1200 & 1400 & 0 \\
\hline Schedule receipts & 1000 & - & - & - & - & - & - \\
\hline Available (On hand=300) & 1300 & 200 & 200 & 400 & 100 & 400 & 0 \\
\hline Net requirements & - & - & 1100 & 400 & 1100 & 1000 & 0 \\
\hline Planned order receipts & - & - & 1500 & 500 & 1500 & 1000 & - \\
\hline Planned order releases & - & 1500 & 500 & 1500 & 1000 & - & - \\
\hline
\end{tabular}

1. Gross requirements come from LMV plannedorder-releases

2. There is an on-hand balance of 300 engine assemblies at the end of week 9

3. There is a scheduled receipt for 1000 engine assemblies in week 10

4. The firm uses a lot size (multiple) of 500 for ordering engine assemblies

5. Safety stock of 100 engine assemblies is desired Bretthauer et al., 2005).

Analysis of case study

The case study details on light motor vehicle (LMV) manufacturing requirements for $800 \mathrm{cc}$ Model are listed in Table $1,2 \& 3$. The company is currently planning production for weeks 10 to 16 . Based on existing orders and demand forecasts, the master production schedule is provided in Table 4.

6. Lead time for engine assemblies is 1 week.

A Large number of economic lot sizing methods are available to management, any one or combination of which may be incorporate in an inventory control system. Consider economic order quantity (EOQ), lot-for-lot (LFL) and period order quantity (POQ) all these methods detailed and compared in MRP schedule for minimizing total cost (Table 9).
Research article

CIndian Society for Education and Environment (iSee)
"Inventory management" http://www.indjst.org
Bhagoria et al. Indian J.Sci.Technol. 
Indian Journal of Science and Technology

Table 9. The net requirements for a material from an MRP schedule are

\begin{tabular}{|c|c|c|c|c|c|c|c|c|}
\hline & \multicolumn{1}{|c|}{ Week } \\
\hline \multirow{2}{*}{$\begin{array}{c}\text { Net } \\
\text { requirement }\end{array}$} & 1 & 2 & 3 & 4 & 5 & 6 & 7 & 8 \\
\cline { 2 - 10 } & 1000 & 0 & 1300 & 800 & 1200 & 1300 & 0 & 800 \\
\hline
\end{tabular}

\begin{tabular}{|c|c|c|c|c|c|c|c|c|}
\hline & \multicolumn{8}{|c|}{ Table 10. Lot-for-Lot method } \\
\hline & \multicolumn{8}{|c|}{ Week } \\
\hline \multirow{2}{*}{$\begin{array}{c}\text { Net } \\
\text { requirement }\end{array}$} & 1 & 2 & 3 & 4 & 5 & 6 & 7 & 8 \\
\hline & 1000 & 0 & 1300 & 800 & 1200 & 1300 & 0 & 800 \\
\hline $\begin{array}{l}\text { Beginning } \\
\text { inventory }\end{array}$ & 0 & 0 & 0 & 0 & 0 & 0 & 0 & 0 \\
\hline $\begin{array}{c}\text { Production } \\
\text { lots }\end{array}$ & 1000 & 0 & 1300 & 800 & 1200 & 1300 & 0 & 800 \\
\hline $\begin{array}{c}\text { Ending } \\
\text { inventory }\end{array}$ & 0 & 0 & 0 & 0 & 0 & 0 & 0 & 0 \\
\hline
\end{tabular}

Table 11. Economic order quantity (EOQ) method

\begin{tabular}{|c|c|c|c|c|c|c|c|c|}
\hline $\begin{array}{c}\text { Economic order } \\
\text { quantity (EOQ) method }\end{array}$ & \multicolumn{10}{|c|}{ Week } \\
\hline & 1 & 2 & 3 & 4 & 5 & 6 & 7 & 8 \\
\hline Net requirement & 1000 & 0 & 1300 & 800 & 1200 & 1300 & 0 & 800 \\
\hline Beginning inventory & 0 & 265 & 265 & 230 & 695 & 0 & 0 & 0 \\
\hline Production lots & 1265 & 0 & 1265 & 1265 & 1265 & 1265 & 0 & 1265 \\
\hline Ending inventory & 265 & 265 & 230 & 695 & 760 & 725 & 725 & 1190 \\
\hline
\end{tabular}

Vol. 3 No. 6 (June 2010)

ISSN: 0974- 6846

$50 /(\mathrm{D} / \mathrm{EOQ})=50 /(40,000 / 1,265)=1.58$ or 2 weeks Carrying cost $=2900(0.40)=1,160$

Changeover Cost $=4(400) \quad=1,600$

Total $=2,760$

Conclusion

We presented results which lead to the determination of the optimal inventory policy and the minimum total cost. Product structure can be any type; each item in the system can have external demands and the cost parameter (carrying cost \& changeover cost). In addition, the proposed precise model can help inventory decision maker to obtain solution closer to global optimum. The promising result motivates the need for further research on the inventory problem with LOT for LOT method. Table 13 shows the cost comparison and it is found that in case for LOT for LOT the cost in minimum.

\section{References}

1. Ashayeri J, Heuts RJM, Lansdaal HGL and Strijbosch LWG (2006) Cyclic production inventory planning and control in the pre-deco industry. Int. J. Prod. Econom. 103, 715-725.

2. Bretthauer KM, Shetty B, syam $S$ and Robert $J$
Table 12. Period order quantity (POQ) method

\begin{tabular}{|c|c|c|c|c|c|c|c|c|}
\hline & \multicolumn{10}{|c|}{ Week } \\
\hline $\begin{array}{c}\text { Net } \\
\text { requirement }\end{array}$ & 1 & 2 & 3 & 4 & 5 & 6 & 7 & 8 \\
\cline { 2 - 10 } & 1000 & 0 & 1300 & 800 & 1200 & 1300 & 0 & 800 \\
\hline $\begin{array}{c}\text { Beginning } \\
\text { inventory }\end{array}$ & 0 & 0 & 0 & 800 & 0 & 1300 & 0 & 800 \\
\hline Production lots & 1000 & 0 & 2100 & 0 & 8000 & 0 & 800 & 0 \\
\hline $\begin{array}{c}\text { Ending } \\
\text { inventory }\end{array}$ & 0 & 0 & 800 & 0 & 1300 & 0 & 800 & 0 \\
\hline
\end{tabular}

It costs Rs. 400 to change over the machines for this material in the affected work center. It costs 0.40 per unit when one unit of this material must be carried in inventory from one week to the next. Identify the lot-sizing method that results in the least carrying and changeover costs for the 8-week schedule (Table 10).

Carrying Cost $=0(.40)=0$

Changeover Cost $=6(400) \quad=\underline{2,400}$

Total $=2,400$

Economic order quantity (EOQ) method (Table 11)

$S=400.00$

$\mathrm{D}=[($ Net Req. for 8 wks $) / 8$ weeks $)]$ (50 weeks/year $)=$ $(6400 / 8)(50)=40,000$

$\mathrm{C}=(0.40$ per week $)(50$ weeks $/$ year $)=20.00$

$E O Q=\sqrt{2 D S / C}=1265$

Carrying cost $=4855(.40)=1,942$

Change over cost $=6(400)=\underline{2,400}$

Total $=4,342$

Period order quantity (POQ) method (Table 12):

$\mathrm{POQ}=(\#$ weeks/year $) /(\#$ orders/year $)=$

Research article

CIndian Society for Education and Environment (iSee)
"Inventory management" http://www.indjst.org

\begin{tabular}{|c|c|c|c|}
\hline Table 13. Cost comparison \\
\hline Method & $\begin{array}{c}\text { Carrying } \\
\text { cost }\end{array}$ & $\begin{array}{c}\text { Change } \\
\text { over } \\
\text { cost }\end{array}$ & $\begin{array}{c}\text { Total } \\
\text { cost }\end{array}$ \\
\hline LFL & 0 & 2400 & 2400 \\
\hline EOQ & 1942 & 2400 & 4342 \\
\hline POQ & 1160 & 1600 & 2760 \\
\hline
\end{tabular}
Vokuka (2005) Production and inventory management under multiple resource constraints. Math. Computer Modeling. 44 (1-2), 85-95

3. Choi S and Enns ST (2004) Multi Item capacitated lot sizing with economics objectives. Int. J. Prod.

Econom. 89 (3), 247-260.

4. Enns ST (1999) The effect of batch size selection on MRP performance, Computers and industrial engineering. 37(1), 15-19.

5. Enns ST (2001) MRP performance effects due to lot size and planned lead times setting. Int. J. Prod. Res. 39(3), 461-480.

6. Enss ST (2002) MRP performance effects due to forecasting bias and demand uncertainty. Eur. J. Oper. Res. 138(1), 87-102.

7. Jose LAS, Sicilia J and Garcia Languna J (2007) An economic lot sizing model with partial backlogging hinging on waiting time and shortage period. J. Appl. Mathematical Modeling. 31, 2149-2159.

8. Khare MK and Sadiwala CM (1987) Computer aided lot sizing in a material requirement planning system, seminar computer aided production engineering, SII$02 / 1$.

9. Robert W. Grubbstrom EW (2006) Multilevel, Multistage capacity constraint production inventory systems in discrete time with non zero lead times using MRP. Int. J. Production Econom. 101, 53-56.

10.Tang O (2004) Simulated annealing and lot sizing problems. Int. J. Prod. Econom. 88, 173-181. 